\title{
Feds stick with decision not to fund refugee health care
}

A lthough Ontario has reinstated many of the aspects of health services for refugee claimants that the federal government withdrew in 2012, Ottawa remains adamant that it will not reconsider the cuts.

"Provincial governments are responsible for health care, and they will foot the bill for decisions about how that health care service is delivered," wrote Alexis Pavlich, press secretary at Citizenship and Immigration Canada, in an email. "If the Ontario government thinks that failed asylum claimants, for example, deserve these services, they are free to pay for it themselves."

Beginning Jan. 1, 2014, the Ontario Temporary Health Program covered most hospital, primary, specialist, diagnostic and laboratory services, in addition to medications listed on the Ontario Drug Benefit Formulary, according to Ontario Ministry of Health spokesperson David Jensen.

The province plans to advise the federal government regularly about the costs of the program, according to Jensen. Ontario currently hosts around 48900 refugee claimants, which is about $55 \%$ of the Canadian total. Ontario's program costs are not expected to exceed $\$ 20$ million, stated Jensen.

In June 2012, the federal government slashed the Interim Federal Health Program, which provided health care to those applying to be refugees. It cut inpatient chemotherapy, vision care, dental benefits, prosthetic limbs, wheelchairs and hip replacements. Claimants also lost drug coverage, barring conditions that pose public health threats.

Later in 2012, the government announced only refugee claimants from "unsafe" countries would get basic health care coverage as they wait for their claims to be processed; refugees from countries deemed "safe," or designated countries of origin, are only treated if their condition poses a public health problem. Under the federal dictate,

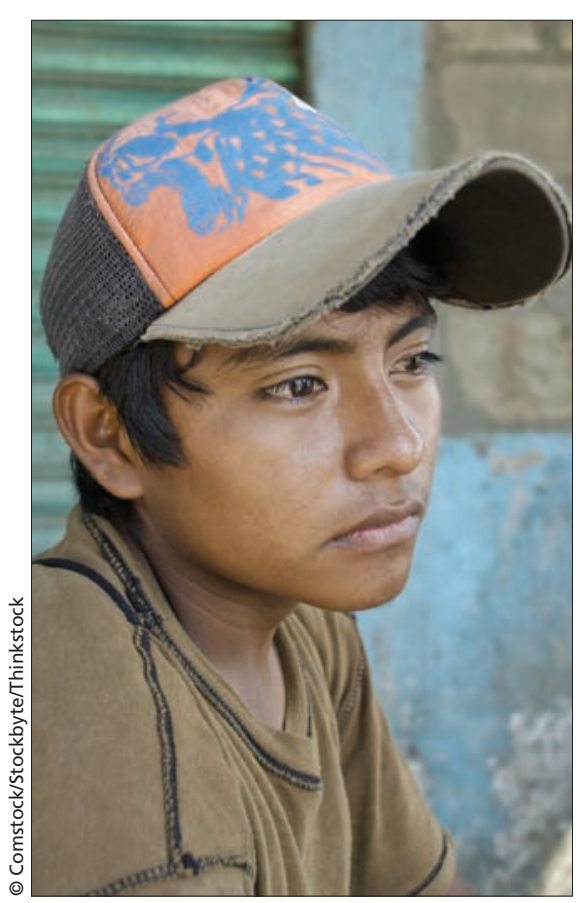

Ontario will provide health care to refugees from "safe" countries, such as Mexico, that the federal government cut more than a year ago.

"failed asylum claimants," or those awaiting deportation or review of a rejected claim, are also not treated unless they pose a threat to the population.

Although Ontario's program does not restore the cuts made in June 2012, with the exception of access to drugs, it does extend health coverage to all refugee claimants, regardless of their country of origin.

Dr. Philip Berger, a founding member of the advocacy group Canadian Doctors for Refugee Care, commended Ontario's decision as ethical and responsible, while calling the federal government "the most hostile and vicious government to refugees and immigrants since the Second World War."

According to Berger, the chief of family and community medicine at St. Michael's Hospital in Toronto, "[doctors] have seen pregnant women who have been unable to secure prenatal care, placing their pregnancy at risk; sick children being turned away from clinics and even patients with cancer being denied chemotherapy."

In addition, many refugee claimants from the so-called safe countries are bona fide claimants, he said. For example, Mexico is on the safe countries list, yet gays and lesbians are fleeing the country because of violence against them.

Berger also criticized former Immigration Minister Jason Kenney for ignoring repeated requests for a meeting from a coalition of representatives of major medical organizations, including the Canadian Medical Association and the Canadian Nurses Association. "He has shown a measure of contempt rarely shown to the leaders of the mainstream medical organizations in Canada."

Despite widespread false reporting that several other provinces have established similar programs, the only one to formally do so is Quebec. The province extends coverage to refugees similar to that available for residents. The Quebec program also covers prescription drugs.

Saskatchewan provides coverage to refugee claimants deemed in need on a case-by-case basis. Ministry spokesperson Carolyn Hamilton was unable to say how many cases have been covered. Refugee claimants in Manitoba not covered by the federal program can access primary care at two refugee clinics in Winnipeg. Nova Scotia is in the process of developing a program to reinstate limited health care for refugee claimants, according to Kirstin Nucklaus, senior policy analyst at the Department of Health and Wellness.

Alberta is considering following suit, said provincial Health Minister Fred Horne. The cost to treat refugee claimants is relatively minor, he said. "Part of the disagreement with the federal government's decision is that, at any one time, this is a small number of people." - Wendy Glauser, Toronto, Ont.

CMAJ 2014. DOI:10.1503/cmaj.109-4689 